\title{
Editorial Expression of Concern: On approximating Mills ratio
}

Zhen-Hang Yang ${ }^{1}$ and Yu-Ming Chu ${ }^{1 *}$

An editorial expression of concern to this article is available online at https://doi.org/10.1186/s13660015-0792-3

"Correspondence:

chuyuming2005@126.com

'School of Mathematics and Computation Science, Hunan City

University, Yiyang, 413000, China
Editorial Expression of Concern: J Inequal Appl 2015, 273 (2015). https://doi.org/ 10.1186/s13660-015-0792-3.

The Editors-in-Chief are issuing this editorial Expression of Concern to alert readers that the first paragraph in the Introduction of this article [1] contains some text that is identical with that in the first paragraph of the Introduction of a previous article by Gasull and Utzet [2]. Zhen-Hang Yang and Yu-Ming Chu have not responded to correspondence about this notice.

\section{Publisher's Note}

Springer Nature remains neutral with regard to jurisdictional claims in published maps and institutional affiliations.

Published online: 03 June 2021

\section{References}

1. Yang, Z.-H., Chu, Y.-M.: On approximating Mills ratio. Journal of Inequalities and Applications (2015). https://doi.org/10.1186/s13660-015-0792-3

2. Gasull, A., Utzet, F: Approximating Mills ratio. Journal of Mathematical Analysis and Applications (2014). https://doi.org/10.1016/j.jmaa.2014.05.034 sharing, adaptation, distribution and reproduction in any medium or format, as long as you give appropriate credit to the original author(s) and the source, provide a link to the Creative Commons licence, and indicate if changes were made. The images or other third party material in this article are included in the article's Creative Commons licence, unless indicated otherwise in a credit line to the material. If material is not included in the article's Creative Commons licence and your intended use is not permitted by statutory regulation or exceeds the permitted use, you will need to obtain permission directly from the copyright holder. To view a copy of this licence, visit http://creativecommons.org/licenses/by/4.0/ 